\title{
THE CHALLENGES OF HOSPITAL INFORMATION SYSTEM IMPLEMENTATION: A CASE STUDY OF A PUBLIC HOSPITAL IN INDONESIA
}

\author{
Fabianus Herman Kurnia Agung Widiyanto, Aris Widayati*) \\ Faculty of Pharmacy, Universitas Sanata Dharma, Campus 3 Paingan, Maguwoharjo, Depok, \\ Sleman, Yogyakarta, 55282
}

Received December 19, 2020; Accepted January 20, 2021

\begin{abstract}
The Indonesian government has mandated using the Hospital Information System (HIS) since 2013. Until now, not all hospitals in Indonesia have implemented HIS, however. Some barriers have prevented them from applying HIS. This study explores the opportunities and barriers regarding implementing the Hospital Information System (HIS) in Indonesia through a public hospital case study. This study applied a qualitative approach. The approach used interviews to gather data using a pre-tested interview guideline. The guideline used several constructs to structure the questions, i.e., predisposing, enabling, reinforcing, barrier, and projected behavior. Participants were different types of HIS users in the studied hospital, i.e., physician, nurse, pharmacist, administrators, laboratory personnel, and Information Technology (IT) personnel. Data were transcribed verbatim and analyzed thematically. The interviews involved twenty-one participants. Nine themes describe HIS implementation challenges in this case study, i.e., familiarity, flexibility, empowerment, discipline, facilities, data sharing, quality assurance, pragmatism, and capacity building. Pragmatism could be a barrier, while the other values would be opportunities. These challenges are promising in guiding HIS implementation success. The values found in this study convince that HIS implementation in Indonesia is promising. Those challenges are required to be taken into account to implement HIS successfully.
\end{abstract}

Keywords: e-health; health informatics; hospital information system; health service; patient safety.

\section{INTRODUCTION}

A Hospital Information System (HIS) facilitates the non-clinical and clinical data integration and real-time. For example,patients registration, billing system, medical record, prescribing, laboratory (Lippeveld etal., 2000; Mehdipour and Zerehkafi, 2013). In the clinical domain, HIS reduces clinical errors, while the administrative inaccuracy is diminished (Demirel, 2017; Mehdipour and Zerehkafi, 2013). In the pressure of financial and human resources burdens, the HIS facility offers efficiency without compromising the quality of the services (Ahmed et al., 2016; Dobrev et al., 2009). Nonetheless, HIS implementation requires massive initial investment regarding information technology tools provision and human resources readiness. Consequently, the higher-income countries are early adopters of the HIS, while lower-income countries have been growing up significantly (Adokiya et al., 2015; Rangraz Jeddi et al., 2013; Saluvan and Ozonoff, 2018; Sharifian et al., 2014).

As one of the lower-middle-income countries, Indonesia has mandated the use of HIS in 2013. HIS implementation aims to assure health service access, including efficiency, professionalism, and patient safety (Kemenkes RI, 2013). Given the high initial cost, Indonesia's hospitals faced delays and unsuccessful HIS implementation. The big hospitals can afford the high initial costs to implement the HIS in the complete function. 
In contrast, the small hospitals tend to partially implement the HIS components or one by one, such as starting from the emedical record, then adding the e-registration in the next year (Asyary et al., 2019; Handayani et al., 2017). Previous studies had revealed barriers to implementing the HIS in Indonesia. The main barriers are the HIS product provision and the users readiness (Asyary et al., 2019; Handayani et al., 2017; Odelia, 2018). Even when the hospital can provide the HIS facilities, the users behavior towards the system operation is still a significant problem, such as knowledge, attitude, and intention (Daerina et al., 2018; Harsono, 2015; Odelia, 2018).

Health professional's behavior problems regarding the HIS use can potentially jeopardize the health care system's strategy and investment. Such a problem requires to be well understood, and therefore the stakeholders can structure the solution. This study aims to explore HIS implementations values through the user's perspectives, including the opportunities and challenges, using a qualitative case study in a public hospital.

\section{METHODS}

This study is a qualitative approach using a case study design involving a public hospital in Indonesia. The public hospital used as the case in this study has implemented HIS for about three years. Therefore, it is a critical step to evaluate HIS implementation in that hospital through this case study. The Ethics Committee had approved the study protocol with letter No.201.3/FIKES/PL/IX/2020.

\section{Participants Selection and Data Collection}

Given the exploratory nature, interviews were applied to gather data. Participants were selected purposively based on their role as HIS users across the hospital's departments, i.e., medical record, administration, finance, ward station, out-patient clinic, Central Sterilization Unit, pharmacy, and IT (Information Technology). There was no gender preference in selecting the participants but considered age variations to anticipate age-related differences in technology adoption. An assessed interview guideline guided the interviews. The guideline consisted of five domains or constructs and ten questions, with several probes. The domains included predisposing, enabling, reinforcing, barrier, and projected behavior. Four questions regarding knowledge, attitude, beliefs, and significances about HIS operation represented the predisposing domain. Two questions were enabling construct, i.e., facilities provision and facilities maintenance, while reinforcing domain guided two questions about coordination within departments and management policy. The barrier domain generated one question, while projected behavior led to one question. Two experts assessed the questions independently. The questions had been revised based on the experts' feedback.

Participants had signed informed consent to participate in this study voluntarily. Before, brief information regarding the study had been delivered to them. The interviews were conducted individually and took 45 to 60 minutes for each participant. Interviews were audio-taped subject to the participants' approvals. Field notes were also created during the interviews.

\section{Data Analysis}

The audio records were transcribed verbatim by a hired research assistant. Two research personnel checked the transcript across the audio records independently to assure the verbatim's accuracy. Data were then analyzed thematically. Firstly, raw codes were extracted deductively based on the domains in the interview guideline. The two research personnel conducted this step individually. Following this step, they then discussed the raw codes to meet the agreement on the formal codes. Secondly, formal codes were synthesized inductively for critical themes. One domain might generate more than one theme. After that, the themes were drawn into a diagram explaining the subject phenomenon, i.e., HIS implementation. 


\section{Data Analysis Quality Assurance}

The independent transcripts checking and coding by two research personnel assured the results' confirmability. Further, discussions between the researchers regarding the suggested formal codes and critical themes in achieving raters' agreement ensured the results' trustworthiness. The raters' agreement is achieved qualitatively through the discussions. Moreover, the purposive selection of the participants with tight criteria, i.e., those who operate HIS in their routine tasks and responsibilities, confirmed the study results transferability, at least in the studied hospital (Korstjens and Moser, 2018).

\section{RESULTS AND DISCUSSION}

Twenty-one participants were interviewed. Respondents characteristics based on the HIS role are ward physician, out-patient physician, ward nurse, out-patient nurse, pharmacist, ward administrator, pharmacy administrator, IT personnel, Central Sterilization Unit administrator, Medical Record personnel, and Finance Department administrator. Such variations were designed to enrich participant's voices from different perspectives and different roles in the HIS. Participant's characteristics can be seen in Table 1. The first step of data analyses resulted in extracted views that were generated deductively based on the domains. Table 2 describes the participants extracted views and experiences. The further analyses step inductively produced nine themes, i.e., familiarity, flexibility, empowerment, discipline, facilities, data sharing, quality assurance, pragmatism, and capacity building. Figure 1 describes the themes interconnection. The themes are explained in the followed paragraphs.

Table 1. Participants' characteristics and practice related HIS (Hospital Information System)

\begin{tabular}{|c|c|c|}
\hline Health profession & $\begin{array}{l}\text { Participants' } \\
\text { numbers }(\mathrm{N}=21)\end{array}$ & Practice related HIS \\
\hline Internist specialist & 1 & e-Medical Record, e-prescribing \\
\hline General Practitioner & 1 & e-Medical Record, e-prescribing \\
\hline In-patient Nurse & 5 & $\begin{array}{l}\text { e-Medical Record, Billing System, Patient Safety } \\
\text { Report }\end{array}$ \\
\hline Pharmacist & 1 & $\begin{array}{l}\text { e-Medical Record, e-prescribing, Billing System, } \\
\text { Patient Safety Report }\end{array}$ \\
\hline Out-patient Nurse & 2 & e-Medical Record, Billing System \\
\hline Pharmacist assistant & 2 & e-prescribing \\
\hline Administrator & 3 & e-Medical Record, e-prescribing, Billing System \\
\hline $\begin{array}{l}\text { Personnel in the Central } \\
\text { Sterilization } \\
\text { Department }\end{array}$ & 1 & Billing System \\
\hline $\begin{array}{l}\text { Personnel in the Medical } \\
\text { Record Department }\end{array}$ & 3 & $\begin{array}{l}\text { e-Medical Record, e-prescribing, Billing System, e- } \\
\text { Claim }\end{array}$ \\
\hline $\begin{array}{l}\text { Personnel in the Information } \\
\text { Technology Department }\end{array}$ & 2 & HIS supporting system \\
\hline
\end{tabular}


Table 2. Participants' views and experiences summary regarding HIS (Hospital Information System) implementation

\begin{tabular}{|c|c|c|}
\hline Domain & Questions & $\begin{array}{l}\text { Participants' views and experiences summary regarding } \\
\text { HIS implementation }\end{array}$ \\
\hline \multirow[t]{5}{*}{ Predisposing } & Knowledge & $\begin{array}{l}\text { All the participants had sufficient knowledge about HIS' } \\
\text { aims. }\end{array}$ \\
\hline & & $\begin{array}{l}\text { Most of the participants had proper skills in HIS } \\
\text { operations. }\end{array}$ \\
\hline & Attitude & $\begin{array}{l}\text { Most of the participants had acknowledged HIS' benefits in } \\
\text { improving their task performance. }\end{array}$ \\
\hline & Beliefs & $\begin{array}{l}\text { Most of them believed that HIS could facilitate } \\
\text { coordination between health care teams and improve } \\
\text { health care services better and faster. }\end{array}$ \\
\hline & Significance & $\begin{array}{l}\text { Participants agreed that discipline and conscientiousness } \\
\text { are essential values that can be learned from HIS } \\
\text { implementation. }\end{array}$ \\
\hline \multirow[t]{2}{*}{ Enabling } & Facilities provision & $\begin{array}{l}\text { HIS facilities are available. There were tablets and } \\
\text { notebooks for doctors to manage their patients. }\end{array}$ \\
\hline & Facilities maintenance & $\begin{array}{l}\text { Facilities maintenance is handled appropriately by IT } \\
\text { personnel. }\end{array}$ \\
\hline \multirow[t]{2}{*}{ Reinforcing } & $\begin{array}{l}\text { Coordination between } \\
\text { departments }\end{array}$ & $\begin{array}{l}\text { Integrated data make coordination among health } \\
\text { professionals easier. }\end{array}$ \\
\hline & Management policy & $\begin{array}{l}\text { Hospital leaders are committed to supporting the HIS } \\
\text { implementation by providing facilities, monitoring } \\
\text { processes, and evaluating results. }\end{array}$ \\
\hline Barrier & $\begin{array}{l}\text { Barrier of } \\
\text { implementation }\end{array}$ & $\begin{array}{l}\text { Most of the participants noticed both technical and human } \\
\text { errors in operating the HIS, for example, temporary power } \\
\text { outage, an overloaded server, system hanging up, pending } \\
\text { orders, data input error, etc. }\end{array}$ \\
\hline $\begin{array}{l}\text { Continues } \\
\text { improvement }\end{array}$ & Projected behavior & $\begin{array}{l}\text { All the participants realized the importance of self- } \\
\text { improvement in operating HIS to support their task } \\
\text { performance and enhance service quality. }\end{array}$ \\
\hline
\end{tabular}

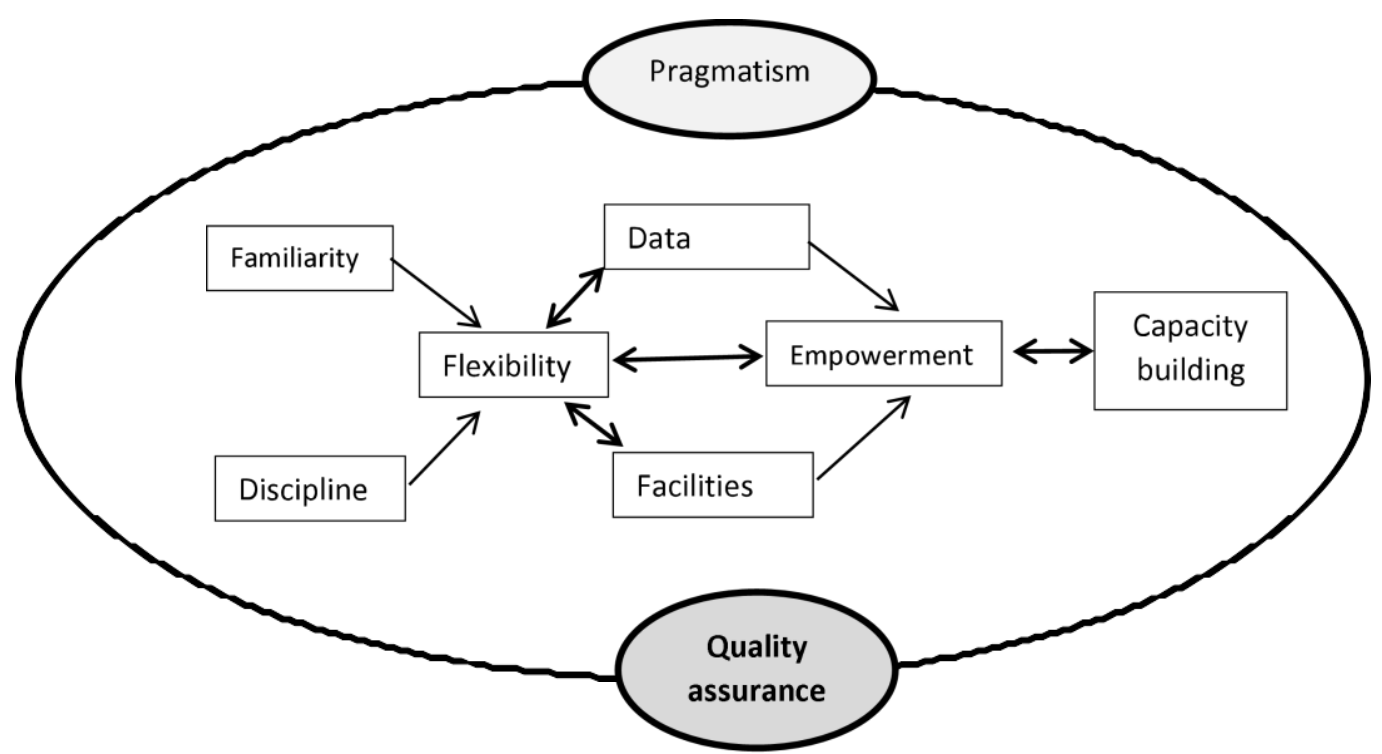

Figure 1: Themes diagram explaining dynamic interaction in the Hospital Information System (HIS) implementation. 


\section{Familiarity}

The familiarity theme was elicited from the participants' responses regarding knowledge and attitude towards HIS implementation. All of them were familiar with HIS operation and HIS' benefits. Familiarity regarding HIS operations will be a crucial point leading to its implementation; otherwise, it will slow down the process.

"....in the beginning, we are confused [how to operate the system]...because we have not yet used to...but, when we used to use it, it will be easy...technology is made to facilitate, not to make us difficult..." (UB09).

\section{Discipline}

Discipline is a value elicited through this study. Discipline in this study refers to the personnel's punctuality in task completion, such as entering or inputting data into the system on-time. Participants in this study were aware that HIS' benefits could be optimally achieved by completing the tasks timely; otherwise, there will be long queues due to the delayed process.

"...HIS is helpful because, by using the billing system, there is no missed bill..." (EY-01).

\section{Flexibility}

Most participants believed that HIS implementation makes them more flexible, particularly in communicating and coordinating with other health care team members and other related units. The flexibility is offered by real-time and integrated data, clinical and non-clinical data, and easy access.

"...all [data] is connected so that it is easier to manage the patients...laboratory [data], radiology, patient's history can be retrieved easily" (TP-04).

\section{Facilities}

In this present study, participants stated that facilities provision is adequate, both hardware and systems. However, some participants also noticed the need to add hardware provision, for example, adding the numbers of notebooks used by physicians in the wards. Moreover, if there is a technical error with the facilities, communication is the key to solve the problem, mainly contacting the IT personnel.

“...ideally, we have a Tablet or Notebook to be brought when visiting the patients, so we do not need to go back to the [nurse] station to enter the data". (OKT-08).

\section{Data sharing}

Participants in this study acknowledged the integrated data facilitated by HIS. They stated that data sharing facilitated them to communicate with other health care team members. Data sharing through HIS also makes the decision-making process more manageable.

"...it helps me coordinate and communicate to [other health professionals]... because by opening the file, we can access the connected data". (JP-20).

\section{Empowerment}

Participants in this study felt that using HIS makes them more confident in communicating with other health care team members. HIS facilitated them to enhance health care team coordination that leads to improving the service quality.

"...first las the doctor who is responsible to the patient], I will activate [the system] to enter the [clinical] assessment results... then, prescription,... then diagnosing and therapy planning. After that, I can confirm with other health professionals, for example, nurse and pharmacist, regarding my responsibility”. (TP-04).

\section{Pragmatism}

Several issues regarding pragmatism were distilled from participants' views. They implied that HIS implementation barriers were more practical than substantial matters; for example, wrong data entry, inadequate skill in operating the system, age-related physical limitations, and unstable electricity supply. They perceived that such kinds of practical barriers were related to the behavioral changes, from manual or paper-based tasks to electronic operations or paperless tasks. 
"...if the electricity supply is not available for 24 hours ...it will be a barrier. Further, data security has also to be managed carefully because the data storage can be expired". (PU-05).

\section{Capacity building}

Participants in this study expressed a high commitment to improving their capacity in using HIS properly. They stated their generous willingness to be involved in training and workshop regarding HIS utilization.

"...from my point of view, we need to update skill, knowledge [through] training, seminars, especially we are now [living] in the digital era". (AS-11).

\section{Quality assurance}

Participants very strongly expressed their views that the hospital leaders have monitored and responded to the HIS implementation well. The hospital management tried to provide the facilities based on the priorities. Participants also stated that the hospital management had provided training, but continuous and regular training is required to maintain users' ability to operate the system.

"...if the system [facilities] is inadequate, the hospital leaders should provide support to get an improved [facilities] performance". (NB-06).

This study underlined the opportunities and barriers in HIS implementation in the Indonesian context through a case study in a public hospital in Central Java Province. Several key concepts, such as familiarity, flexibility, empowerment, discipline, facilities, and data sharing, create opportunities to foster HIS implementation success. Pragmatism might be a barrier, but capacity building and quality assurance could promise HIS implementation sustainability in this context. This reported study highlights HIS implementation optimism nuance, especially in developing countries like Indonesia.

\section{Familiarity and Discipline}

Most participants in this study were aware that HIS implementation would improve their task performance. Their acceptance of this concept encouraged them to become familiar with HIS operation. It is in line with a previous study that stated that HIS acceptance is influenced by performance expectancy (Sharifian et al., 2014). An initial investment in making users familiar with HIS operations is significant (Farzandipur et al., 2016; Khalifa, 2016), particularly regarding time invested by users and their willingness to adopt an innovation. Consequently, it will be foreseen inefficiencies, such as prolonged service time and overloaded pending tasks. These consequences will only happen at the beginning of implementation when users commit to having discipline value. The adopted technology quality would boost users' acceptance, which leads to intrapersonal factors, such as discipline (Ebnehoseini et al., 2019; Kuo et al., 2018).

\section{Flexibility, Facilities, and Data Sharing}

HIS facilitates digitally-professional communication using integrated clinical data between health professionals in real-time (LaBranche, 2011). It is proven in this reported study that users convinced of flexibility in terms of coordination and communication within health care teams using real-time integrated data sharing. Nevertheless, several studies convinced dissatisfaction regarding HIS' communication and information systems in their context (Khalifa, 2016; Lammintakanen et al., 2010; Sharifian et al., 2014). It depends on the type and quality of the HIS operated. Therefore, adequate facilities and reliable data sharing provisions are very crucial. However, in the developing world, reliable data remains a problem, although facilities provision might not be an issue in prominent health care institutions (Asyary et al., 2019; Handayani et al., 2017; Ismail et al., 2015). Thus, HIS implementation seems a good starting point in managing and providing reliable data for better health care services.

\section{Empowerment}

According to the HOT-fit concept, human is an essential factor in HIS implementation, among technology and organization, to produce benefits optimally (Urbach and Müller, 2012). Participants in this study 
implied that HIS empowered them, especially in communicating among health professionals and decision-making. This theme is central, mainly when people are the main problem in HIS implementation (Sadoughi et al., 2013). People tend to be reluctant to adopt new technology because it forces them to leave their comfort zone. When users realize that HIS makes them empowered, it will be easier to accept this adapted technology.

\section{Pragmatism}

Participants in this study depicted pragmatic attitudes towards technical errors in using HIS, such as inadequate electricity supply and system hanging. This issue has been reported in many previous studies as a barrier to HIS implementation. Pragmatism is not always destructive, especially in developing countries. Such an issue could be an essential factor in promoting an evolution process (La Nauze, 2002). On the other hand, pragmatism could lead to a lesser acceptance regarding adopting new technology, mainly when management support is not adequate. However, as mentioned above, empowerment could potentially balance pragmatism. The managerial role is very crucial in making pragmatism and empowerment atmosphere balance.

\section{Capacity building and quality assurance}

As highlighted by the HOT-fit concept, three constructs lead the success story of new technology implementation, i.e., Human, Organization, and Technology (Urbach and Müller, 2012). Capacity building and quality assurance cover those three issues. Users in this study expected training to enhance their capability in using the HIS. The organization is expected to provide regular training and qualified technology. Although participants in this study stated that facilities provision is adequate, technology quality issues remain to exist. Such issues also have been acknowledged by several previous studies regarding HIS implementation in the Indonesian context (Odelia, 2018; Puspitasari et al., 2013; Saputra, 2016). Therefore, quality assurance plays a crucial role in the HIS implementation success. Quality assurance could guarantee Human, Organization, and Technology to fulfill the required standards to optimize its benefits.

This study is not without its limits. Given the nature of the qualitative approach and the case study design applied, the results are not intended to be generalized in all the Indonesian hospitals; instead, each institution has its characteristics. However, this qualitative approach had explored deeply the underlying factors that either support or prevent the HIS implementation success. Therefore, others can learn from this study's findings.

\section{CONCLUSION}

HIS implementation in Indonesia is promising. Although data quality entered and generated by the system somehow remains an issue, the users' performance and support from management and authority could enhance HIS's benefits in facilitating a high quality of health service in Indonesia.

\section{REFERENCES}

Ahmed, Z., Barber, N., Jani, Y., Garfield, S., Franklin, B.D., 2016. Economic Impact of Electronic Prescribing in the Hospital Setting: A Systematic Review. International Journal of Medical Informatics, 88, 1-7.

Asyary, A., Nur Prasetyo, A.K., Eryando, T., Gerke, S., 2019. Users' Perception of the Hospital Information System in a Maternity Hospital in Lampung, Indonesia. Kesmas,14(2), 76-81.

Daerina, S.R.F., Mursityo, Y.T., Rokhmawati, R.I., 2018. Evaluasi Peranan Persepsi Kegunaan dan Sikap terhadap Penerimaan Sistem Informasi Manajemen Rumah Sakit (SIMRS) di Rumah Sakit Seila Riska Faricha Daerina 1 Daerah Kalisat. Jurnal Pengembangan Teknologi Informasi dan Ilmu Komputer, 2(11), 5950-5959.

Demirel, A.P.D.D., 2017. Effectivness of Health Information System Applications: Clinical Information and DiagnosisTreatment Systems in Turkey. European 
Journal of Multidisciplinary Studies, 2(5), 122-131.

Dobrev, A., Jones, T., Stroetmann, K., Vatter, Y., Peng, K., 2009. Report on the Socioeconomic Impact of Interoperable Electronic Health Record (EHR) and Prescribing Systems in Europe and Beyond, URL

https://www.scimp.scot.nhs.uk/wpcontent/uploads/documents/ECS/EHRI_fi nal_report_2009.pdf, (acessed 9.9.20).

Ebnehoseini, Z., Tabesh, H., Deldar, K., Mostafavi, S.M., Tara, M., 2019. Determining the Hospital Information System (His) Success Rate: Development of a New Instrument and Case Study. Open Access Macedonian Journal of Medical Sciences, 7(9), 1407-1414.

Farzandipur, M., Jeddi, F.R., Azimi, E., 2016. Factors Affecting Successful Implementation of Hospital Information Systems. Acta Informatica Medica, 24(1), 51-55.

Handayani, P.W., Hidayanto, A.N., Pinem, A.A., Hapsari, I.C., Sandhyaduhita, P.I., Budi, I., 2017. Acceptance Model of a Hospital Information System. International Journal of Medical Informatics, 99, 11-28.

Harsono, A., 2015. Analisis Implementasi Sistem Informasi Manajemen Rumah Sakit Umum Daerah (SIM-RSUD) Terintegrasi di Provinsi Kalimantan Barat. Eksplora Informatika, 5(1), 11- 22.

Ismail, N.I., Abdullah, N.H., Shamsuddin, A., 2015. Adoption of Hospital Information System (HIS) in Malaysian Public Hospitals. Procedia - Social and Behavioral Sciences, 172, 336-343.

Kemenkes RI, 2013. Peraturan Menteri Kesehatan Republik Indonesia No. 82 Tahun 2013 tentang Sistem Informasi Manajemen Rumah Sakit, Jakarta.

Khalifa, M., 2016. Evaluating Nurses Acceptance of Hospital Information Systems: A Case Study of a Tertiary Care Hospital, in: Studies in Health Technology and Informatics, 225, 78-82.

Korstjens, I., Moser, A., 2018. Series: Practical Guidance to Qualitative Research. Part 4: Trustworthiness and publishing. European Journal of General Practice, 24(1), 120-124.

Kuo, K.M., Liu, C.F., Talley, P.C., Pan, S.Y., 2018. Strategic Improvement for Quality and Satisfaction of Hospital Information Systems. Journal of Healthcare Engineering, Sep 12, 3689618.

La Nauze, J., 2002. Our Responsibility in a Developing World: From Ethics to Pragmatism. Clinical and Experimental Ophthalmology, 30(2), 66-71.

LaBranche, B., 2011. Rapid Clinical Information Drives Patient Safety. Nursing Management, 42(12), 29-30.

Lammintakanen, J., Saranto, K., Kivinen, T., 2010. Use of Electronic Information Systems in Nursing Management. International Journal of Medical Informatics, 79(5), 324-331.

Lippeveld, T., Sauerborn, R., Bodart, C., 2000. Design and Implementation of Health Information Systems, URL https://apps.who.int/iris/handle/10665/42 289, (accessed 9.9.20).

Mehdipour, Y., Zerehkafi, H., 2013. Hospital Information System (HIS): At a Glance. Asian Journal of Computer and Information Systems, 1(2), 54-61.

Odelia, E.M., 2018. Pengembangan Kapasitas Organisasi Melalui Penerapan Sistem Informasi Manajemen Rumah Sakit (SIMRS) Untuk Meningkatkan Mutu Pelayanan Kesehatan di RSUD dr. Mohamad Soewandhie Surabaya. Kebijakan dan Manajemen Publik, 6(1), 1-8.

Puspitasari, N., Permanasari, A.E., Nugroho, H.A., 2013. Analisis Penerapan Sistem Informasi Manajemen Rumah Sakit Menggunakan Metode UTAUT dan TTF. Jnteti, 2(4), 225-232.

Rangraz Jeddi, F., Abazari, F., Moravveji, A., Nadjafi, M., 2013. Evaluating the Ability of Hospital Information Systems to Establish Evidence-based Medicine in Iran. Journal of Medical Systems, 37(2), 9904-9905.

Sadoughi, F., Kimiafar, K., Ahmadi, M., Shakeri, M.T., 2013. Determining of Factors Influencing the Success and 
Failure of Hospital Information System and Their Evaluation Methods: A Systematic Review. Iranian Red Crescent Medical Journal, 15(12), e11716.

Saluvan, M., Ozonoff, A., 2018. Functionality of Hospital Information Systems: Results from a Survey of Quality Directors at Turkish Hospitals. BMC Medical Informatics and Decision Making, 18(1), 6.

Saputra, A.B., 2016. Indentifikasi FaktorFaktor Keberhasilan Implementasi Sistem Informasi Manajemen Rumah Sakit. Jurnal Penelitian Pers dan Komunikasi
Pembangunan, 19(3), 135-148.

Sharifian, R., Askarian, F., Nematolahi, M., Farhadi, P., 2014. Factors Influencing Nurses' Acceptance of Hospital Information Systems in Iran: Application of the Unified Theory of Acceptance and Use of Technology. Health Information Management Journal, 43(3), 23-28.

Urbach, N., Müller, B., 2012. The Updated DeLone and McLean Model of Information Systems Success, in Introduction Systems Theory, Vol. 1, Springer, New York. 